\title{
The Hittite 'Theogony' or Song of Going Forth (CTH 344): Stratification of Mythical Traditions
}

With a Suggested Translation for KUB 33.120 Vs. I $19 f$.

\author{
Christian Zgoll \\ Seminar für Klassische Philologie, Georg-August-Universität Göttingen, \\ Göttingen, Germany \\ czgoll@uni-goettingen.de
}

\begin{abstract}
The present paper deals with the controversially discussed relationships between the gods Alalu, Anu, Kumarbi, and Tarhunnaš in the Hittite Song of Going Forth (CTH 344). On the basis of a new philological analysis, of comparisons with theogonies or succession myths in other ancient cultures and on the background of considerations on the cross-cultural stratification of various mythical traditions in the surviving Hittite text, various proposals on the genealogical relationship of the deities in question are weighed against each other and reasons are presented for the plausibility of the proposed new translation and general reconstruction that the divine kingship always passes from father to son within a single genealogical line.
\end{abstract}

\section{Keywords}

Hittite mythology - succession myths - theogony - CTH 344 - Song of Going Forth - Hesiod - Alalu - Kumarbi

At the beginning of the Hittite Song of Going Forth, ${ }^{1}$ the office of king of the gods passes by way of battles first from Alalu to Anu, then from Anu to Kumarbi; Kumarbi, in turn, later brings the weather god into being (Hurrian

1 For this reconstruction of the title, see Corti 2007. 
Teššub, Hittite Tarhunnaš). ${ }^{2}$ Once in the text reference is made to the kinship of the three deities Alalu, Anu, and Kumarbi (Vs. I 19 f.):

Vs. I $19 \mathrm{~d} K u-m a r-b i-i s ̌ \mathrm{~d} A-l a-l u-w a-a s ̌ \mid N U M U N-\check{S} U\rceil^{\mathrm{Vs}}$ I $20 \mathrm{~d} A-n u-u-i m e-n a-$ ah-ha-an-ta za-ah-[ha-in] pa-iš.

The sumerogram NUMUN ("seed, offspring") is written here with Akkadian possessive suffix $-\check{S} U$ (3rd person singular: "his"). ${ }^{3}$ However, the reference of the enclitic possessive pronoun is not as clear as it might at first sight seem to be. There are two possible references and therefore two different possible translations, with different consequences for the interpretation of the relationship between Alalu, Anu, and Kumarbi.

\section{$1 \quad$ Kumarbi as Descendant of Alalu}

Normally, translation $(\mathrm{A})$ is found:

Kumarbi, the descendant of Alalu, went into battle against Anu.

Thus, ${ }^{\mathrm{d}} A$-la-lu-wa-aš $\lceil\mathrm{NUMUN}-\check{S} U\rceil$ is usually taken to refer to Kumarbi, and Kumarbi is regarded as a descendant of Alalu (see figure 1$){ }^{4}$

2 Instead of the convention of using only the root of the proper name (Tarhunna-), the form of the name is rendered in the nominative singular (Tarhunnaš).

3 The reading NUMUN-ŠS could be confirmed on the basis of a new examination of the photographs by Beckman 2011: 27; the reading (ibid.) of the name of the god in the nominative d $A$-nu-uš (instead of ${ }^{\mathrm{d}} A-n u-u-i$ ) - is obviously an oversight in view of the relatively quite legible cuneiform characters (visible on the photo).

4 Without exception in the research literature consulted; a selection: Ünal 1994: 829: "Kumarbi, Alalus Sproß"; Hoffner 1998: 42: "Kumarbi, Alalu's offspring"; Rieken et al. 2009; 2010 ad стн 344: "Kumarbi, des Alalu Nachkomme"; Beckman 2011: 27: "Kumarbi, scion of Alalu"; van Dongen 2012: 34: "Alalu's son Kumarbi"; Bauer et al. 2015: 163: "Kumarbi, des Alalu Nachkomme"; Bachvarova 2016: 93: "Kumarbi, the seed of Alalu." The possessive suffix cannot be rendered in the translation. 


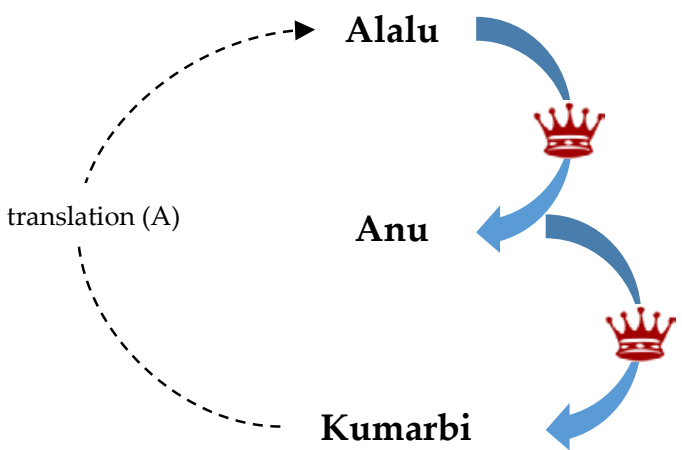

FIGURE 1 Succession of the gods and Kumarbi as descendant of Alalu

This translation (A) raises two questions of content or, more precisely, of genealogy:

1. What does "descendant" mean, i.e. what degree of relationship connects Kumarbi to Alalu?

2. Should Anu have a kinship status in the structure Alalu - Anu - Kumarbi, and if so, of what kind?

The following explanations may be daunting to read, but they are necessary to raise or sharpen awareness that the issue to be clarified here is not only complex, but actually complicated.

Ad 1: Since the conceptual content of NUMUN (or Luw. warwalan-) is unspecific, it can concretely denote "son," but also "grandson," or an even more distant degree of relationship (great-grandson, great-great-grandson, etc.); from the context, the first two possibilities in particular (son or grandson) come into consideration, since further generations are nowhere else in view.

a) Kumarbi = son of Alalu. Problem: There is no mention of Kumarbi as son of Alalu anywhere in the description of Alalu's reign. In connection with this the question arises, why Kumarbi, if he is Alalu's son, appears in the course of the mythical song only in the third place of the succession and not directly following his father Alalu.

b) Kumarbi = grandson of Alalu. Problem: The question remains unanswered why Kumarbi should be defined by his relationship as a grandson rather than by that of a son to his father. 
Ad 2: As far as the position of Anu is concerned, there are the following possibilities: Between Anu on the one hand and Alalu and Kumarbi on the other hand there is a) no kinship relationship at all, or he has b) a kinship relationship to both or c) only to one of the two.

a) Anu = not related to Alalu and Kumarbi, while Kumarbi is son (or grandson) of Alalu. In this case, Kumarbi's war against Anu can be interpreted as an action of revenge because the foreign, unrelated god Anu drove Kumarbi's father (or grandfather) from the throne.

b) Anu $=\alpha$ ) brother of Kumarbi, and both in turn could be sons of Alalu and it would be a fratricidal war; or Anu $=\beta$ ) son of Alalu and father of Kumarbi and is warred against by his own son. ${ }^{5}$

c) $\quad$ Anu $=\alpha$ ) son of Alalu but has nothing to do with Kumarbi, or Anu $=\beta$ ) father of Kumarbi but has nothing to do with Alalu. ${ }^{6}$

In view of these complicated findings, the openness of the text, and the multitude of possibilities, nothing remains to solve the question of the kinship between Alalu, Anu, and Kumarbi but to look for arguments for plausible scenarios and to check whether the translation of the text can be brought into agreement with a proposed interpretation or should be modified.

The secondary literature reveals that two of the outlined scenarios have found support so far, both based on the translation (A) of the verses KUB 33.120 I $19 \mathrm{f}$. cited above, which, however, as indicated, is not the only possible rendering. Problematic here is primarily the relationship between Alalu, Anu, and Kumarbi, not so much that of Kumarbi and Teššub/Tarhunnaš, although there are differences in the accentuation of the filiation here as well.

\subsection{Two Rival Dynasties of Gods}

HOFFNER devotes about half a page to the problem. He argues for a combination of case 1.a) and 2.a), according to which Kumarbi is to be regarded as the son of Alalu, and Anu is related neither to Alalu nor to Kumarbi; he is joined by other researchers such as BAUER (et al.). ${ }^{7}$

Moreover, HoffNer understands not Kumarbi but rather Anu to be the father of Teššub (/Tarhunnaš). This father-son relationship of Anu and Teššub/ Tarhunnaš is already not quite as clear-cut as it first appears to be, since Kumarbi, by biting off the testicles of Anu becomes "pregnant" with Teššub/ Tarhunnaš, which makes him a second father of Teššub/Tarhuunnaš besides Anu, so that one may legitimately ask who is now to be regarded as "the" father of

5 Further double kinship relations would be conceivable, but then appear ever more remote.

6 Brotherly relationships, etc., could also be conceivable, but again are always more remote.

7 Hoffner 1975: 138 f. and 1998: 41. Following Bauer et al. 2015: 162; see also Rutherford 2016: 13. 
the weather god: Anu, who donates the semen, or Kumarbi, who bears and "gives birth" to Teššub/Tarhunnaš (cf. Zeus, who as father bears Dionysus and who gives birth to Athena and is without question regarded as the "father" of Dionysus and Athena). Hoffner sharpens these alternatives, in that he considers Kumarbi as unrelated and only Anu as the "actual" father of Teššub/Tarhunnaš. ${ }^{8}$

On this basis, he reconstructs two different genealogical lines, each of which fights and replaces the other in the kingship: ${ }^{9}$ Anu dethrones his opponent Alalu (whom Hoffner does not regard as related), Kumarbi then avenges his father Alalu by dethroning the opposing Anu, and Anu's son Teššub (/Tarhunnaš) in turn avenges his father Anu by later dethroning Kumarbi (see figure 2). ${ }^{10}$ HOFFNER states in summary:1 "Thus it is indisputable that we have two rival dynasties here with kingship alternating between them in their struggles." Such an interpretation is quite consequential; several scholars see in the fact that according to this reconstruction the rule does not pass from father to

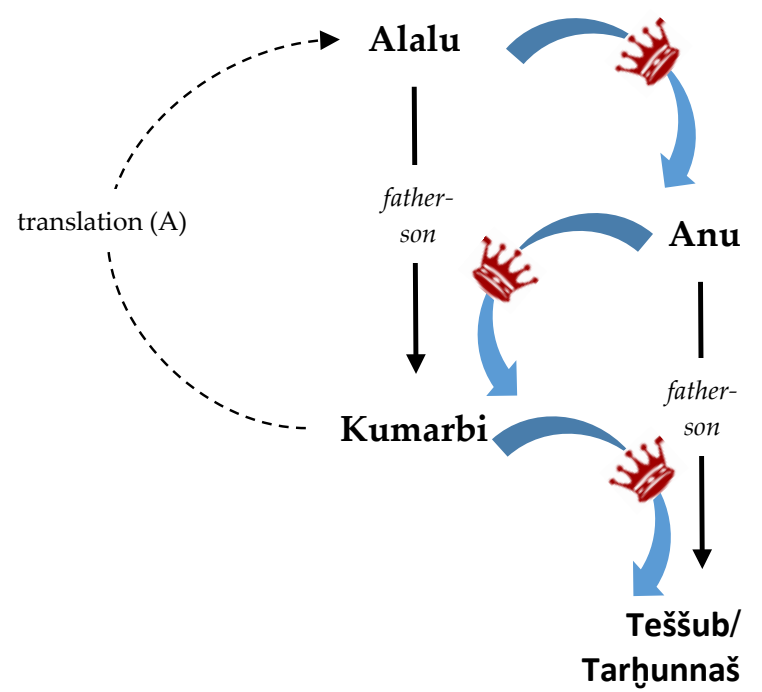

FIGURE 2 Reconstruction of the filiations and the succession according to HOFFNER

8 See also López-Ruiz 2010: 93 (italics in the original text): "For now let us just note that Kumarbi is not Anu's son but Alalu's, as Teshub is not Kumarbi's son but Anu's, though born through Kumarbi as Kumarbi is impregnated by the swallowing of Anu's genitals."

9 See also Cors i Meya 1999-200o: 347.

10 This last change of rulership is not evident in the Song of Going Forth itself (the end of which has survived only in very fragmentary form).

11 Hoffner 1975: 139. 
son within a single genealogical line a decisive difference between the Song of Going Forth and Hesiod's Theogony. ${ }^{12}$

\subsection{A Dynasty of Gods of Four "Calendar Kings"}

That HOFFNER's reconstruction is not "indisputable" is already shown by the fact that an alternative interpretation has been proposed. HAAs argues for the above-mentioned case 2.b) $\beta$ ), which assumes Alalu as Anu's father and Anu as Kumarbi's father (in the continuation, Kumarbi as father of Teššub/ Tarhunnaš), and which then entails case 1.b) (Kumarbi not as son, but as grandson of Alalu). ${ }^{13}$ HAAs thus assumes only a single genealogical line. One reason for this is that he is attempting to interpret the mythical material in the Song of Going Forth as a calendar myth ("Kalendermythos"), in which Anu, Alalu, Kumarbi, and Teššub represent four month-kings ("Monatskönige") who alternate and emerge directly from one another (see figure 3 ).

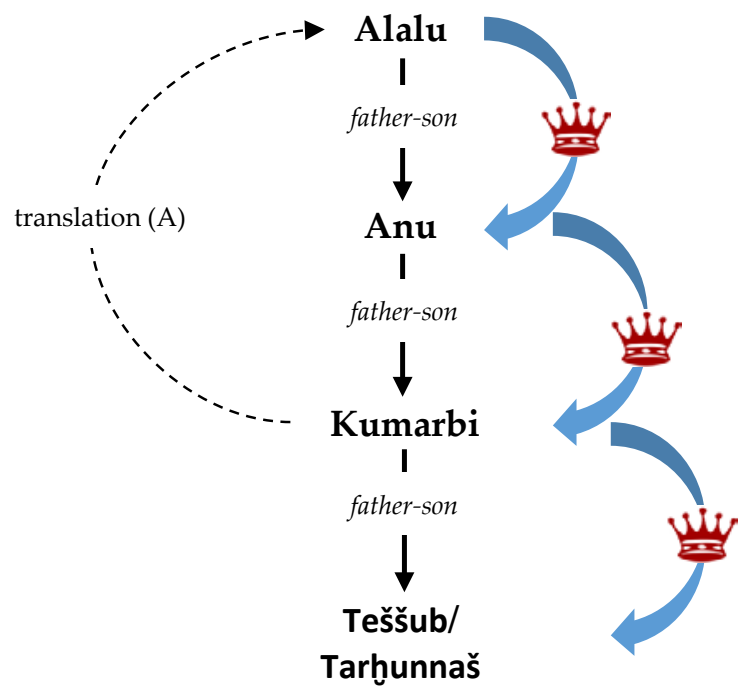

FIGURE 3 Reconstruction of the filiations and the succession according to HAAS

12 For example, Rutherford 2016:13: "there are three stages (generations in the Greek but not in the Hittite)"; likewise van Dongen 2011: 194; explicitly also López-Ruiz 2010: 93: "A distinctive characteristic of the Hurro-Hittite Succession Myth, and one in which it clearly differs from Hesiod's, is that the succession line is not straight from father to son, as in the case of Ouranos-Kronos-Zeus."

13 Haas 1994: 85; 2006: 136 (from which the following quotations in the main text are taken). 
The interpretation of HAAS may at first reflect an intuitive interpretation of the textual findings, but the interpretation as a "calendar myth" with four "month-kings" seems to involve non-trivial presuppositions and would require a more detailed justification in order to make such an interpretation plausible (see also below). HAAs dedicates a short page to the discussion of the problem; he does not appear to take account of the strongly differing interpretation of HofFNer anywhere. ${ }^{14}$ Precisely the striking difference between the mutually exclusive interpretations of HAAS and HOFFNER shows that the problem stands in need of a more detailed elaboration.

In this context, a fundamental consideration is important. If one looks at the deities involved, then it becomes clear that the Song of Going Forth in the present version must be regarded as a highly stratified product of different mythical traditions. ${ }^{15}$

This is already evident from the Hittite reworking when, among other things, Kumarbi's son, the Hurrian weather god Teššub, is replaced by the Hittite weather god Tarhunnaš and thus a deity is placed in a narrative context foreign to it; the Hittite name of the god is clearly recognizable by corresponding (i.e. Hittite) phonetic complements at the end of the name of the god, logographically written as dIŠKUR. ${ }^{16}$ This "overwriting" of the Hurrian Teššub by the Hittite Tarhunnaš remains superficial insofar as in the Song of Going Forth the contexts of the narrative material otherwise point to Teššub. ${ }^{17}$ Nevertheless, the Hittites, as is often the case elsewhere, attracted and adapted foreign gods and traditions and narratives associated with them like a magnet.

The fact that a Teššub myth is appropriated here for the Hittite weather god and supreme god-king Tarhunnaš is a reliable indication that in the only fragmentarily preserved end of the Song of Going Forth there must have been a

14 Hoffner 1998: 41, in turn, does not address the interpretation proposed by Haas 1994, although Haas' work is included in Hoffner's bibliography.

15 On myths as transmedial narrative materials, see Zgoll 2019: 25-52; on the stratification of myths see in detail ibid., 270-519.

16 For example, кUB 33.120 Vs. I 31, II 35.44.75. Schwemer 2001: 448 n. 3717 points this out explicitly. On the preferable reading of the character combination AN-IM as dIŠKUR (not ${ }^{\mathrm{I}} \mathrm{M}$ ) when used in reference to the weather god, see ibid., 29-31.

17 Cf. for example the reference to the numinous bull Šeri in кUв 33.120 Vs. II 18, who pulls the chariot of Teššub together with the bull Hurri; for details see Schwemer 2001: 477-83. 
positive outcome for the weather god, i.e., a victory of the weather god over rival divine powers. This "success story" of the Hurrian weather god Teššub is now appropriated for the Hittite's own weather god Tarhunnaš much like, for example, the Assyrians in Mesopotamia did with the success story of the (Babylonian) god Marduk in the poem Enüma eliš (Song to Marduk). ${ }^{18}$ In their variant of this text the name "Marduk" was consistently replaced by the spelling AN.ŠAR, ${ }^{19}$ which is a learned spelling for the native city and state god Aššr. A minimal change with a great effect: as a result of this intervention, it is no longer the Babylonian god Marduk who is the most powerful among all gods, the victor over Tiāmtu and creator of parts of the world, but the Assyrian god Aššur. ${ }^{20} \mathrm{~A}$ very similar effect is achieved in the Song of Going Forth by replacing the Hurrian Teššub with the Hittite Tarhunnaš.

If one were to assume only a single layer of revision, i.e., if one were to speak of a younger Hittite revision of an older Hurrian original, one would hardly do justice to the findings; the stratification is clearly more complex. In addition to the Hittite Tarhunnaš (for Teššub), the names of the god Alalu and the sky god Anu refer to the Sumero-Akkadian or Mesopotamian ${ }^{21}$ culture, respectively, while Kumarbi (like Teššub) belongs to Hurrian mythology (see figure 4).

Alalu

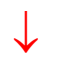

\section{Sumero-Akkadian}

Anu

$\downarrow$

Kumarbi

Hurrian

\section{Tarhunnaš}

\section{Hittite}

FIGURE 4 Stratification in the Song of Going Forth on the basis of the protagonists involved

18 For this title of the poem, see Gabriel 2014: 107-11.

19 An overview of all the text passages with the corresponding deviations or substitutions in Kämmerer and Metzler 2012: 28.

20 See Zgoll 2019: 499.

21 Here and elsewhere in this article, "Mesopotamian" is used not as a designation of a geographical area (which includes the Hurrians), but as a simplifying term for the SumeroAkkadian dual culture. 
These observations lead to an important conclusion: stratigraphically speaking, there have never been any relations between some of these deities, since they come from different traditions. On the basis of this complex but unambiguous finding, it is then also quite improbable that the four main deities were from the beginning carefully coordinated with each other and should symbolize a seasonal cycle, in which organically and consistently one "month-king" emerges from the other, as HAAs assumes in the context of his "Kalendermythos" interpretation. Without going into further details, a difficulty already shows up in the fact that HAAs posits Alalu therefore as "month-king" for the months October to December, ${ }^{22}$ because this god is equated in an incantation with "storm tide."23 This is a single document that may refer to the manifestation in which Alalu is to be reckoned when his wrath flares up; the majority of the documents, however, clearly indicate that the Mesopotamian deity Alala (for the form of the name see below) is not to be related to storm tides but to agriculture and grain. ${ }^{24}$ But this field of activity and the season connected with it is already occupied in the reconstruction of HAAs by the "grain god" Kumarbi, ${ }^{25}$ which leads to the unlikely interpretation of Alalu as a storm tide deity. To return from this detail to the general point: the unsure relations and filiations among these gods from different traditions are enough to make the assumption of a cycle of coordinated "month-kings" appear fundamentally problematic.

With the help of the considerations about multiple stratification in the Song of Going Forth, the circumstance can also be explained why the Hittite, stratified variant does not formulate the relations between the gods clearly: it stands to reason that the references were deliberately left open. This is also supported by the fact that the lines quoted at the beginning are the only ones in the text known so far in which a relationship between the three deities mentioned is explicitly addressed.

Since the gods Alalu and Anu come from Mesopotamia and e.g. Alalu is also attested in the contact zone of Syria, ${ }^{26}$ it is quite possible that the Hurrians adopted these two gods from there. ${ }^{27} \mathrm{~A}$ reconstruction of the stratification history of the mythical material in the Song of Going Forth is, however, anything but uncomplicated; if one restricts oneself first only to the Mesopotamian-Hurrian

\footnotetext{
22 Haas 1994: 85.

23 See ibid.: 83 with n. 19 (on the invocation, where the deity is called "Alulu"), and 85 .

24 See the evidence in $C A D A / 1,328$, s.v. aläla. See also van Dongen 2011: 194.

25 On Kumarbi as "grain god" see Haas 1994: 169.

26 See Haas 1994: 110 with n. 22, 113 with n. 5 o.

27 This is also the assumption of Haas 1994: 113. In this case it would be conceivable that the Hurrians already adopted Alalu and Anu at such an early stage in history that these deities were no longer perceived as "foreign."
} 
strata, there are among other things the following possibilities (further intermediate stages are also conceivable):

a) The Hurrians placed the Mesopotamian deities Alalu and Anu before their own gods Kumarbi and Teššub (where they were not before), thus extending a shorter narrative material.

b) The Mesopotamian names Alalu and Anu have displaced the names of older (already existing) Hurrian predecessors.

c) The Hurrians took over the entire narrative material in its main features from Mesopotamia and left only the first two gods, Alalu and Anu, "in the original," but in the succession afterwards "overwrote" two Mesopotamian deities with their own Hurrian gods Kumarbi and Teššub (just as the Hittites then overwrote Teššub by Tarhunnaš). ${ }^{28}$

On which ways it came to the multi-layered, at some intermediate stage transmitted by a Hittite text, Hittite-Hurritic-Sumero/Akkadian narrative material, ${ }^{29}$ can presumably no longer be clarified. If in earlier stages of the transmission of this mythical material the number of the involved deities was already the same as in the Hittite transmitted variant, then it is to be assumed that this group of deities was more uniform, that the mutual relations were clearer, and that such a more uniform conception has given at least certain basic lines to the stratified, Hittite transmitted final product. Since the question of the number, names, and relationships of the involved deities in assumed preliminary versions, however, runs into a wall, because we do not possess further testimonies ${ }^{30}$ and the Hittite text leaves much open, all that remains to us beside the consideration of general plausibilities is to look in other directions, on the one hand at neighboring cultures, on the other at the history of reception.

28 Thus, for example, Kumarbi, after coming to power, takes up his kingship in the city of Nippur, which was the residence city of the Mesopotamian god Enlil (KUB 33.120 Vs. I $42 \mathrm{f}$ ), to mention only one further overlapping of different mythical traditions or strata in the Song of Going Forth. With the tradition of mythical narratives in ancient Near Eastern cultures we only grasp the famous tip of the iceberg; compare, e.g., the testimony for the fight of the weather god against a numinous sea monster, in which a single source can remain the sole testimony for centuries (on the mythical pattern of the fight of the weather god against the sea see in detail Ayali-Darshan 2020). Thus, the only evidence so far for the Old Babylonian period (see Ayali-Darshan 2020: 204, with translation and commentary of the text ibid. 205-11) is found hidden in the subordinate clause of a Mari letter (A. 1968), see its original edition in Durand 1993: 43-5; see also Schwemer 20o1: 226-37 (edition, translation, and interpretation).

29 On the distinction between mythical material and text, more generally between a narrative material and its medial concretization in the form of a text, image, dance, or the like, see Zgoll 2019: 25-41.

30 On the problem of assumed "original versions" of myths in general, see ibid.: $57-61$, $135^{-43}$. 
We turn first to the Hurrian deities Kumarbi and Teššub. According to the Hittite version, a father-son relationship exists between the two, albeit a special one, since Kumarbi, as already mentioned, becomes "pregnant" with Teššub by biting off the testicles of Anu, which makes him a second father of Teššub besides Anu. The duality of fathers for the same god can be taken as an important indication that there is a stratification behind this complicated construction. ${ }^{31}$ In the present case, this construction indicates that Kumarbi and Teššub were not always and everywhere viewed as being in a father-son relationship. Data derived from the history of the Hurrian religion makes this seem even more plausible: Kumarbi was closely associated with the Hurrian royal city of Urkeš, while the city of Kumme was considered an ancient center of worship for Teššub. ${ }^{32}$ Thus, in the father-son connection of these two high deities an inner-Hurrian stratification can already be detected, in which independent deities as heads of two different local pantheons were harmonized with each other by establishing a kinship. In the Song of Going Forth, the implicit conflict regarding the hierarchical relationship of the two high gods is decided in favor of Teššub. ${ }^{33}$

As far as the Sumero-Akkadian deities Alalu and Anu are concerned, the relation is not quite so clear. ${ }^{34}$ Alalu stands as "Alala" (the Mesopotamian variant of the god's name) with his wife Belili in the list of gods An = Anum (I 1-24) among the ancestors ("fathers and mothers") of the sky god An/Anu before the primeval pair of gods En-iri-ula and Nin-iri-ula, with whom the list ends. ${ }^{35}$ Since other sources make clear that the list of generations is to be read from top to bottom, and since Alala and Belili are in the penultimate position, they are to be interpreted there as the grandparents of An/Anu. Comparable generation lists of primeval god pairs are also found in Babylonian incantations, only without having Anu as the final generation. With GEORGE and LAMBERT it is to be assumed that due to parallel sequences these incantations are transmitting alternative traditions to the series of the ancestors of Anu. In three

31 On kinship relations as indications of stratification processes in myths, see ibid.: 479-9o.

32 I owe this hint to the anonymous reviewer; on this matter see Wilhelm 1982: 69-74.

33 On myths as battle grounds for competing world views, where conflicts over the power of interpretation are fought out, see in detail Zgoll 2019: 413-39.

34 See on the following Lambert 2013: 417-26, and with reference to СтH 344 ibid. 423, 425 and 448; also George 2016: 8-12.

35 An edition of the Mesopotamian god lists is currently being prepared by M. Krebernik and A. George for publication in the series Oriental Religions in Antiquity. 
cases Alala and Belili stand in the last place, so that in these cases both can be regarded as parents of Anu. ${ }^{36}$ This is not proof, but it does suggest that the sequence of Alalu and Anu in the Hittite Song of Going Forth is based on this last mentioned line of tradition, so that as with the Hurrian deities Kumarbi and Teššub a father-son relationship can also be assumed in the case of the Mesopotamian gods Alalu and Anu. Thus, a father-son relationship between both Alalu and Anu and between Kumarbi and Teššub (/Tarhunnaš) is virtually assured. The question still remains as to the relationship between Anu and Kumarbi.

In Hesiod's Theogony, which close relations to the Hurrian-Mesopotamian "theogony" in a Hittite influenced version have for a long time been no longer in dispute, ${ }^{37}$ the parallel structured succession of the main gods Gaia - Uranos Kronos - Zeus always passes rule from father or (with Gaia) mother to son. In comparisons between the theogonic myths as transmitted in the Hittite tradition and as found in Hesiod, the parallelism between Alalu and Gaia is commonly overlooked, and occasionally the incorrect assertion is even explicitly made that there is a distinction between a quadripartite succession in the Song of Going Forth and a tripartite one in Hesiod; ${ }^{38}$ the successions are in fact parallel not only with respect to the "classification" of the deities involved, ${ }^{39}$ but also with regard to their number.

From these observations it can be concluded that an ancient line of reception most likely assumed for the Hittite original a) a relationship of all four deities and $b$ ) the most uncomplicated and obvious one, i.e. a direct parentchild relationship. Thus, in analogy to the parent-child series in Hesiod, there is a series with the same degrees of relationship in the Song of Going Forth (see figure 5 ).

Admittedly, such an argument ex post does not constitute proof, but it at least provides a well-founded basis for the plausibility of the assumption of a single "dynasty of gods," if one also takes into account that the parallels between Hesiod's Theogony and the Hittite Song of Going Forth observed thus far do not concern large structures alone, but extend also to individual details.

$36 \quad$ See Lambert 2013: $417 \mathrm{f}$.

37 More recently, e.g., Strauss Clay and Gilan 2014; Rutherford 2016.

38 See, e.g., Ünal 1994: 803; Haas 2006: 136; van Dongen 2011: 194 f; Haas and Koch 2011: 287; Bauer et al. 2015: 162; Rutherford 2016: $12 \mathrm{f}$.

39 On the connection of Kumarbi or Kronos with agriculture, see. Haas 1994: 169 and Baudy 1999: 866. 


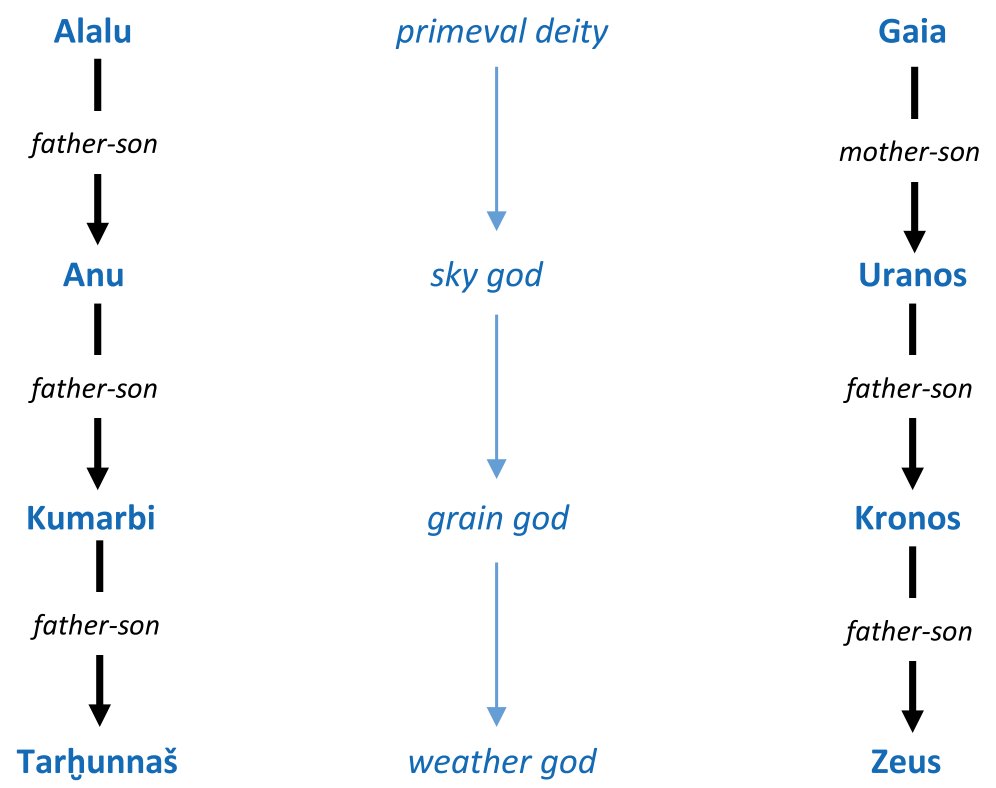

FIGURE 5 Parallel filiations in the Song of Going Forth and Hesiod's Theogony

As a further parallel we can also cite god-lists from Ugarit. ${ }^{40}$ There the following sequence is attested, which can be understood as the framework of a succession myth:41

- ilib (primeval deity, literally "god of the father") ${ }^{42}$

- il (high god El)

- $d g n$ (deity of agriculture and grain, Dagān, who is equated with Kumarbi) ${ }^{43}$

- $b$ l spn (weather god Baal from the divine mountain Zaphon).

The diversity of traditions, themselves partly divergent, is made clear by the fact that a Hurrian list of gods, which has also been handed down from Ugarit, switches the positions of the weather god (Teššub) and Kumarbi; it manifests the following sequence: in atn (primeval deity, literally "god of the father") - il (high god El) $-t t b$ (the weather god Teššub) - kmrb (the grain god Kumarbi). ${ }^{44}$ A possible explanation for this deviant finding is that there could be an Urkeš tradition (see above) behind this list, one according to which the succession culminated not in Teššub, but in Kumarbi.

40 I owe this tip to the anonymous reviewer.

41 KTU 1.47 and KTU 1.118 or RS 1.017 and RS 24.264+. See Niehr 1998: 51-5; Pardee 2002: 11-24.

42 On the preceding $i l s p n$ in KTU 1.47 (RS 1.017) as a heading summarizing the following deities ("the gods of Zaphon"), see Niehr 1988: 53 .

43 On the deity and the equation of Dagān with Kumarbi, see Haas 1994: 163-71.

44 RS 24.295; see Dietrich and Loretz 1988: 300-5. 


\section{$5 \quad$ Kumarbi as Descendant of Anu}

The question remains whether the Hittite text allows a translation which comes closer to this idea of a succession from father to son. On the basis of the above considerations the following translation (B) is to be discussed:

Vs. I $19 \mathrm{~d} K u-m a r-b i-i s ̌ \mathrm{~d} A-l a-l u-w a-a s ̌ \mid N U M U N-\check{S} U\rceil^{\mathrm{Vs}}$ I $20 \mathrm{~d} A-n u-u-i m e-n a-$ ah-ha-an-ta za-ah-[ha-in] pa-iš.

Kumarbi went into battle against Anu, the descendant of Alalu.

The new suggestion is thus to refer the phrase $\mathrm{d} A$-la-lu-wa-aš $\mid \mathrm{NUMUN}-\check{S} U$ | not to Kumarbi but to Anu (Anu as a descendant, more specifically as a son, of Alalu, see figure 6).

Whether such an analysis of the text is possible depends not on the geni-

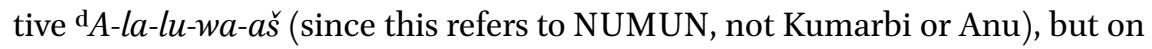
the question of whether NUMUN-ŠU in this case must be read as a nominative apposition to Kumarbi ("Kumarbi, the descendant of Alalu"), or could also be a dative apposition to Anu, one not further determined by a phonetic complement ("against Anu, the descendant of Alalu"). Now, appositions in Hittite can stand before or after the noun to which they belong. ${ }^{45}$ Furthermore,

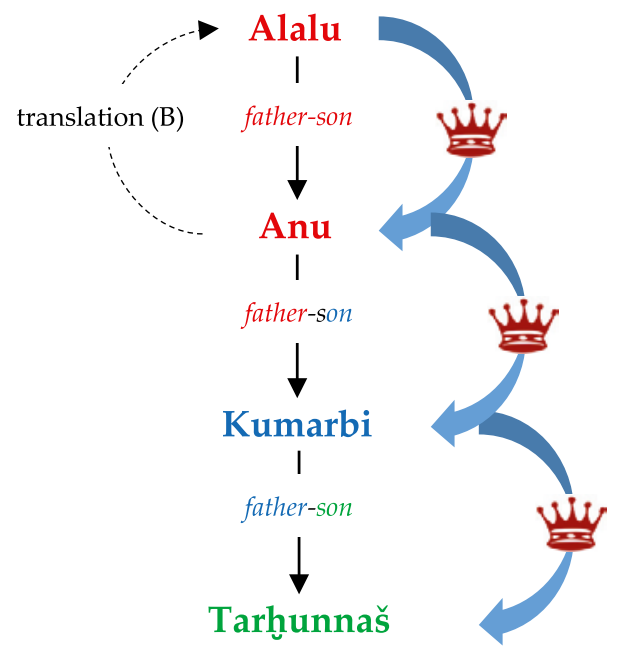

FIGURE 6 Reconstruction of filiation, succession, and stratification according to ZGOLL

45 See the examples in Hoffner and Melchert 2008: 236. 
sumerograms as appositions in an oblique case do not necessarily have to be determined by a phonetic complement. In KBo 3.1+ II 9 f. one finds a very similar case, namely an appositional (in this case: postposed) sumerogram with an Akkadian possessive suffix (NIN-SÚ), which from the context must stand in the accusative ("his sister," as accusative object to harta: he had "his sister" [sc. as wife]); this accusative is not, however, indicated by a phonetic complement. ${ }^{46}$

Translation (B) is therefore not only grammatically possible, but it eliminates the problem of having to explain why Kumarbi should have been defined by his being a grandson (so HAAs) rather than by his being a son. For in view of the discussion above, here it is not the Hurrian Kumarbi as grandson of the Mesopotamian Alalu, but - per the Mesopotamian tradition - it is the Sumero-Akkadian $\mathrm{An}(\mathrm{u})$ as son of the likewise Sumero-Akkadian god Alalu that is meant. ${ }^{47}$ Furthermore, this interpretation does away with the problematic and not very plausible assumption that in a highly stratified product, one which is consciously cautious regarding relationship statements, the assertion of a cross-cultural divine relationship should have been made, as was the case according to the above-mentioned interpretation of HOFFNER. If any statement of relationship were made at all, one would sooner expect it to concern the relationship between the Mesopotamian gods Alalu and Anu (see translation B) or between the Hurrian gods Kumarbi and Teššub, rather than of all things a relationship between the Hurrian Kumarbi and the Mesopotamian Alalu.

When HofFNer, based on translation (A) cited above, interprets Alalu as the father of Kumarbi and Anu as the father of Těšub (/Tarhunnaš) and reconstructs two genealogical lines, each fighting and replacing the other in rule, various difficulties result. First, it remains unexplained why the idea of two "rival dynasties" is not reflected, not even in preliminary fashion, in Greek reception. Moreover, the question arises why Kumarbi was then not directly referred to as a "son" but rather only vaguely as a "descendant" of Alalu. More grievous still is the fact that this reconstruction must operate with the problematic assumption of two cross-cultural god-relationships: on the one hand with the Mesopotamian Alalu as father of the Hurrian Kumarbi, and on the

46 In the transcription of Hoffner and Melchert ibid.: ${ }^{\mathrm{m}}$ Telipinušš $=a=z{ }^{\mathrm{f}}$ Ištapariyan hantezziyan NIN-SÚ harta.

47 The vague designation NUMUN, "descendant," may be connected in this case with the fact that according to some Mesopotamian traditions, as explained above, other deities too could be intercalated between Alala and Anu, so for example the pair En-iri-ula and Nin-iri-ula in An = Anum I 22 f.; thus, a certain ambiguity existed whether Anu was to be regarded as son or grandson of Alala. 
other with the Mesopotamian Anu as father of the Hurrian Teššub, ${ }^{48}$ while the Mesopotamian evidence, according to which it is precisely Alalu (/Alala) and Anu who are related, remains unconsidered.

If one follows translation (B), then the culture-internal father-son relationship Alalu-Anu results organically. The father-son relationship Kumarbi-Teššub is, as already discussed, more complex, since Teššub has, strictly speaking, two fathers, Anu and Kumarbi, and is also overwritten by the Hittite weather god Tarhunnaš. Nevertheless, the text leaves no doubt about a direct filiation of Kumarbi to Teššub/Tarhunnaš.

Most problematic in the Hittite final version is the "seam" between the Sumero-Akkadian $\mathrm{An}(\mathrm{u})$ and the Hurrian Kumarbi. Because of the "leap between cultures" any closer relationship statement has here been consciously avoided. That Kumarbi, despite the cultural gap, was regarded or should be regarded as son of Anu is possible, but not provable. If Alalu and Anu on the one hand and Kumarbi and the Teššub-substituting Tarhunnaš on the other were each seen in a father-son relationship, it stands to reason that Anu and Kumarbi were also interpreted as father and son. Such a reconstruction of kinship, while not proven, is further corroborated when we include consideration of the Mesopotamian parallel of the sequence of the primeval gods, which in the list of gods $A n=$ Anum leads in a single genealogical line of "fathers and mothers" toward the sky god An/Anu, and also by a look at the reception in Hesiod's Theogony, in which all successive deities likewise stand in a parentchild relationship.

Generally, in ancient theogonies the idea that the succession of different primordial gods takes place within a single genealogical line is the rule. ${ }^{49}$ This is also an indication of the improbability of HOFFNER's reconstruction of two rival dynasties; the assumption of such an exception would at the very least require a more detailed plausibility check.

Further evidence for a father-son relationship of Anu and Kumarbi outside of the Song of Going Forth, where both are brought closely together, is hardly to be expected due to the different cultural origins of these two deities. There is, however, one passage in which Kumarbi is referred to as the son of a deity whose name begins with "A-," but the following lines are not legible. Building

48 Whereas Kumarbi, as already discussed above, is also to be regarded as the (albeit involuntary) "father" of Teššub/Tarhunnaš, since the latter is born from him, i.e. there is a parent-child relationship, regardless of whether Kumarbi is assigned the term "mother" or "(second) father" in this particular case.

49 An overview of theogonies or succession myths in various ancient cultures is provided by Zgoll 2022. 
on the results obtained above, it is likely that in this text Anu is to be regarded as Kumarbi's father. Thus, when interpreting the interrupted name of the god beginning with "A-" in KUB 33.110 Vs. II 11', the conclusion of which is the father of Kumarbi $\left(\dot{u}-u k{ }^{\mathrm{d}} K u\right.$-mar-bí-in DUMU $\left.\mathrm{d}[A]-[\ldots]\right)$, the supplement "Anu" 50 is preferable to the addition of HOFFNER, who conjectures "Alalu" (with a question mark) based on his interpretation of KUB 33.120.51

The supplement of Anu as father of Kumarbi in KUB 33.110 (Vs. II 11') and the proposed translation (B) of KUB 33.120 (Vs. I 19 f.) support each other. The philological textual work, together with the above considerations on myth stratification and history of myth reception, leads to the following results:

1. There are plausible arguments for the assumption that the succession of the deities Alalu - Anu - Kumarbi in the Hittite Song of Going Forth is to be interpreted as a sequence of two successive father-son conflicts proceeding within a single genealogical line.

2. In these arguments the reference to parallels in the history of reception (Hesiod's Theogony) plays a subordinate role; more important is

- the parallelism with similarly ancient or older theogonic myths, in which there is usually succession of different primordial gods within a single genealogical line,

- the argumentation for the probability of a father-son relationship between Alalu and Anu based on Mesopotamian sources (a fatherson relationship between Kumarbi and Tě̌šub/Tarhunnaš results from the Song of Going Forth itself),

- $\quad$ and the insight that the kinship statement made in KUB 33.120 Vs. I

$19 \mathrm{f}$. can be analyzed philologically in a different way than hitherto.

3. By reconstructing the succession sequence not as a struggle between rival dynasties but as a succession of battles within a single genealogical line, as well as by taking into account the fourfold (not threefold) number of god-chiefs taking turns in ruling, the already strong parallelism

$50 \quad$ So Siegelová 1971: 48: DUMU ${ }^{\mathrm{D}} A\left[-\right.$ NIM$^{(\text {?)}}$; Haas 1994: 168: "Kumarbi ist der Sohn des Himmels-(Gottes) und der Enkel des Alalu" (with n. 103); Rieken et al. 2009 (ad Cтн 348.I.7) ad locum: "Kumarbi, A[nus?] Sohn."

Hoffner 1998: 53 . 
between the Hittite Song of Going Forth and Hesiod's Theogony becomes even more apparent.

4. The Song of Going Forth incorporates various mythical traditions, which can be seen not least in the different origins of divine protagonists. The "international diversity" of the deities involved is to a certain extent tamed and put into a genealogically structured narrative, behind which the different strata of the tradition remain partially recognizable. In view of the fact that the Hittite stratum in the Song of Going Forth is clearly thinner than the Mesopotamian stratum (at least in the textual fragments that have survived so far), it is problematic to shorten the stratification to Hittite-Hurrian elements. ${ }^{52}$ Even if this is hardly practicable due to the length and unwieldy bulk of the description, if one wanted to do justice to the complexity of the myth stratification in the Song of Going Forth, one would have to speak of a "Hittite reworked Hurrian-Mesopotamian theogony," even more precisely of a theogonic narrative material with Hittite-Hurrian-Sumero/Akkadian strata in a Hittite text.

\section{Acknowledgements}

I would like to thank Daliah Bawanypeck and Annette Zgoll as well as the anonymous reviewer of the peer review process for their valuable feedback on this paper, Josephine Fechner for research support, and Christopher Callanan for helpful advice and improvements to the English version. I would also like to thank the German Research Foundation (DFG) for funding the DFG Research Group 2064 "STRATA - Stratification Analyses of Mythical Materials and Texts in Antiquity," in the context of which the foundations for the present article were laid, and for supporting the open access publication.

52 Cf. e.g. Ünal 1994: 803; Haas 1994: 82: "Der hurritisch-hethitische Mythenzyklus vom Gerstengott Kumarbi”; or López-Ruiz 2010: 91: “This Anatolian myth is called Hurro-Hittite because of the Hurrian origins of the myth, adapted by the Hittites." The importance of Mesopotamian influence in the Song of Going Forth can be seen, among other things, in the prominent role of the god Ea or the city of Nippur (see also van Dongen 2012: 37 and 64). On the importance of Mesopotamian elements, see also van Dongen 2011: 188; on the possibility of still further influences, such as from the Egyptian culture, see Rutherford 2016: 17 , with references in n. 67 . 


\section{References}

Ayali-Darshan, N. 2020: The Storm-God and the Sea: The Origin, Versions, and Diffusion of a Myth throughout the Ancient Near East, ORA 37, Tübingen.

Bachvarova, M. R. 2016: Wisdom of Former Days: The Manly Hittite King and Foolish Kumarbi, Father of the Gods, in: I. Zsolnay (ed.), Being a Man: Negotiating Ancient Constructs of Masculinity, New York, 83-111.

Baudy, G. 1999: Kronos, in: Der Neue Pauly 6, 864-70.

Bauer, A., et al. 2015: „Das Lied vom Ursprung" (СTH 344), in: B. Janowski and D. Schwemer (ed.), Weisheitstexte, Mythen und Epen, TUAT NF 8, Gütersloh, 162-5.

Beckman, G. 2011: Primordial Obstetrics. "The Song of Emergence" (стH 344), in: M. Hutter and S. Hutter-Braunsar (ed.), Hethitische Literatur: Überlieferungsprozesse, Textstrukturen, Ausdrucksformen und Nachwirken, Akten des Symposiums vom 18. bis 20. Februar 2010 in Bonn, AOAT 391, 25-33.

Clay, J. Strauss, and A. Gilan 2014: The Hittite 'Song of emergence' and the Theogony, in: Philologus 58, 1-9.

Cors i Meya, J. 1999-2000: Traces of the Ancient Origin of Some Mythic Components in Philon of Byblos, in: M. Molina, I. Márquez Rowe, and J. Sanmartín (ed.), Arbor Scientiae: Estudios del Próximo Oriente Antiguo dedicados a Gregorio del Olmo Lete con ocasión de su 65 aniversario, AuOr 17-18, Barcelona, 341-8.

Corti, C. 2007: The So-called "Theogony" or "Kingship in Heaven": The Name of the Song, in: SMEA 49, 109-21.

Dietrich, M., and O. Loretz. 1988: Ugaritische Rituale und Beschwörungen, in: C. Butterweck et al. (ed.), Rituale und Beschwörungen II, TUAT II/3, Gütersloh, 299-357.

Dongen, E. V. 2011: The 'Kingship-in-Heaven'-Theme of the Hesiodic Theogony: Origin, Function, Composition, in: GRBS 51, 180-201.

Dongen, E. V. 2012: The Hittite Song of Going Forth (СтH 344): A Reconsideration of the Narrative, in: $\mathrm{WdO}_{42}, 23-84$.

Durand, J.-M. 1993: Le mythologème de combat entre le dieu de l'orage et la mer en Mésopotamie, MARI 7, 41-61.

Gabriel, G. 2014: Enūma eliš - Weg zu einer globalen Weltordnung: Pragmatik, Struktur und Semantik des babylonischen „Lieds auf Marduk", ORA 12, Tübingen.

George, A. R. 2016: Die Kosmogonie des Alten Mesopotamien, in: Gindhart, M., and T. Pommerening, (ed.), Anfang \& Ende: Vormoderne Szenarien von Weltentstehung und Weltuntergang, Zaberns Bildbände zur Archäologie, Darmstadt, 7-25.

Haas, V. 1994: Geschichte der hethitischen Religion, HdO 1/15, Leiden.

Haas, V. 2006: Die hethitische Literatur: Texte, Stilistik, Motive, Berlin.

Haas, V., and H. Koch. 2011: Religionen des alten Orients, Teil 1: Hethiter und Iran, Grundrisse zum Alten Testament 1/1, Göttingen. 
Hoffner, H. A. 1975: Hittite Mythological Texts: A Survey, in: H. Goedicke and J. J. M. Roberts (ed.), Unity and Diversity: Essays in the History, Literature, and Religion of the Ancient Near East, Baltimore, 136-45.

Hoffner, H. A. 1998: Hittite Myths, 2nd ed., Atlanta.

Hoffner, H. A., and H. C. Melchert. 2008: A Grammar of the Hittite Language: Part 1: Reference Grammar, LANE 1/1, Winona Lake.

Kämmerer, T. R., and K. A. Metzler. 2012: Das babylonische Weltschöpfungsepos Enūma elîš, AOAT 375, Münster.

Lambert, W. G. 2013: Babylonian Creation Myths, Winona Lake.

López-Ruiz, C. 2010: When the Gods Were Born: Greek Cosmogonies and the Near East, Cambridge.

Niehr, H. 1998: Religionen in Israels Umwelt: Einführung in die nordwestsemitischen Religionen Syrien-Palästinas, Ergänzungsband 5 zum Alten Testament, Würzburg.

Pardee, D. 2002: Ritual and Cult at Ugarit, sBLwAw 10, Atlanta.

Rieken, E. et al. (ed.) 2009: hethiter.net/: СTH 348.I.7 (TX 2009-o9-01, TRde 2009-o9-01).

Rieken, E. et al. (ed.) 2009: hethiter.net/: стн 344 (TRde 2009-o8-31).

Rieken, E. et al. (ed.) 2010: http://titus.uni-frankfurt.de/texte/etcs/anatol/hittite/cthtx/ cthtx.htm?cthtx122.htm (Copyright Tiтus Project, Frankfurt a/M, 6.8.2010).

Rutherford, I. 2016: Kingship in Heaven in Anatolia, Syria and Greece: Patterns of Convergence and Divergence, in: Audley-Miller, L. and B. Dignas (ed.), Wandering Myths: Transcultural Uses of Myth in the Ancient World, Berlin, 3-22.

Schwemer, D. 2001: Die Wettergottgestalten Mesopotamiens und Nordsyriens im Zeitalter der Keilschriftkulturen: Materialien und Studien nach den schriftlichen Quellen, Wiesbaden.

Siegelová, J. 1971: Аppu-Märchen und Hedammu-Mythus, Sвт 14, Wiesbaden.

Ünal, A. 1994: Der Mythos vom Königtum der Götter und Kumarbi, Стн 344, in: K. Hecker et al., Weisheitstexte, Mythen und Epen: Mythen und Epen II, TUAT III/2, Gütersloh, 828-30.

Wilhelm, G. 1982: Grundzüge der Geschichte und Kultur der Hurriter, Grundzüge 45, Darmstadt.

Zgoll, C. 2019: Tractatus mythologicus: Theorie und Methodik zur Erforschung von Mythen als Grundlegung einer allgemeinen, transmedialen und komparatistischen Stoffwissenschaft, Mythological Studies 1, Berlin.

Zgoll, C. 2022: Theogonie, in: RAC 31/249 (in press). 